\title{
STUDENT TEAMS-ACHIEVEMENT DIVISION TO IMPROVE STUDENTS' WRITING SKILL
}

\author{
Sri Wahyuni \\ Sekolab Tinggi Agama Islam Negeri (STAIN) Kediri \\ wabyu_uni78@yaboo.com
}

\begin{abstract}
Acquiring writing skill needs a lot of practices, and to produce a piece of writing needs a long process; hence, the appropriate method of the teaching and learning is very important to belp students master writing skill. This article aims at reporting a research on the implementation of Student Teams-Achievement Division (STAD) as an alternative teaching method to improve students' writing skill. Through Classroom Action Research design, the researcher did the research at fourth semester students of English Education study program of STAIN Kediri in academic year 2012-1013. The research procedures are planning, implementing, observing, and reflecting. The findings show that the implementation of STAD can improve the students' writing skill which were indicated by the high percentage of the students' active involvement and positive response on the implementation, and the students' product of writing in which all of writing components can achieve good level in marking scheme as the minimum level.
\end{abstract}

Keywords: writing skill, teaching and learning process, STAD

\begin{abstract}
Abstrak
Peroleban ketrampilan menulis memerlukan latiban yang banyak, dan untuk membuat selembar tulisan membutubkan proses yang lama; oleh karena itu, metode pengajaran dan pembelajaran yang sesuai adalab sangat penting untuk membantu siswa menguasai ketrampilan menulis. Artikel ini bertujuan melaporkan sebuab penelitian tentang penerapan Student Teams-Achievement Division (STAD) sebagai alternative metode pengajaran untuk meningkatkan ketrampilan menulis siswa. Melalui metode penelitian tindakan kelas, peneliti melakukan penelitian pada mahasiswa semester empat program studi pendidikan bahasa Inggris di
\end{abstract}


STAIN Kediri pada tabunajaran 2012-2013. Prosedurpenelitian tersebut adalah perencanaan, penerapan, observasi, danrefleksi. Hasil penelitian menunjukkan babwa penerapan STAD dapat meningkatkan ketrampilan menulis mahasiswa yang diindikasikan dengan tingginya presentasi keterlibatan siswa secara aktif dan respon positif terhadap penerapan, serta hasil tulisan mahasiswa yang semua komponen tulisannya dapat mencapai tingkat baik dalam skema penilaian sebagai tingkat minimal yang harus dicapai.

Kata kunci: keterampilan menulis, proses pembelajaran, STAD

\section{Introduction}

Writing is one of English language skills which must be mastered by college students. It plays an important role in personal and professional life. Thus, it has become one of the essential components in English for General Purposes (EGP) and English for Academic Purposes (EAP) curricula. The multi various pedagogical purposes range from reinforcement, training and imitation to communication (generally in the early stages of instruction), fluency and learning (at the intermediate and the more advanced level). Based on the literacy-based approach, the language learning should focus more on literacy skill, reading and writing. The emphasis on the reading and writing skill is intended to support the learning process. Writing can assist the students who have problems in speaking and it is one of self-enhancement of the students' learning style (Raimes, 1987:23).

According to Hadfield and Hadfield (1990: 30), writing is different from speaking. In speaking, someone can acquire the skill naturally as s/he grows up, but writing needs to be learned since s/ he cannot acquire writing skill naturally. So, teachers need to find an effective approach to solve the problem. The usual things associated with writing are word choices, the use of appropriate grammar (such as subject-verb agreement, tenses and articles use, syntax, and word order), mechanics (punctuation, spelling) and organization of ideas into a coherent and a cohesive text. In composing grammatical and comprehensible English sentences, almost learners face a lot of difficulties to choose the appropriate words, and to formulate grammatical sentences. This happens 
because writing ability requires the mastery of the rule of sentences, the mastery of vocabulary and the knowledge of mechanics. Therefore, to master these requirements are not easy for the ESL or EFL students.

Furthermore, there are at least three causal factors of the writing difficulties (Byrne, 1998: 50). The first factor is linguistic problem. The second is psychological problem (writing is a solitary activity in which we have to write our own without the possibility of interaction). The third is cognitive problem due to the need to master the written form of the language and certain structures which are less used in speaking, or perhaps not used at all, but they are important for an effective communication in writing.

A number of studies on writing have been carried out in Indonesia. In fact, generally, writing is hard for almost learners. In the classroom setting, the researchers reveal that writing is the most difficult skill to learn (Mukminatin, 1997: 93). It is believed that developing writing skill is more complicated than other language skills. The students were unhappy, unmotivated and spent too much time before they could start doing the exercises on writing (Basuni, 2004:89). From these findings described above, it can be concluded that there are some problems found in the teaching and learning writing.

Several causes of the problem can be derived from the teaching and learning process, either from the teacher's side or the students' side. From the teachers' side, the teacher employed unvaried conventional teaching strategies. The teacher was not very innovative and tended to apply monotonous strategies in assigning students to write without giving any guidance for students in the writing process. The teacher-centered approach with less students' participation in teaching and learning process made students unmotivated to learn.

The students of English Education study program of STAIN Kediri also faced the problems above. In this study program, writing is one of the basic obligatory courses and the facts prove that students' writing achievements are not satisfactory. Based on the observation when teaching writing at STAIN Kediri, the researchers found that the students got problem in writing. They could not express their 
ideas in writing clearly and accurately because of lack of vocabulary, low grammatical mastery and organization of writing. The lack of students' vocabulary made them confront barrier in expressing their thought onto paper smoothly. They also lacked grammar; therefore, they made many grammatical inaccuracies in their writing. The students had difficulties to organize texts well even though they had been supplied with model texts in the initial activity. Even though there were available topics to explore, they could not write smoothly because they do not know what to convey and develop the topics. They lost ideas and got stuck in the middle of writing, even from the beginning of writing. Arising from those problems, they were reluctant to write English texts, even though, writing is very important for them in writing a scientific paper, proposal and even a thesis. Finally, the students had no motivation to write and it made writing as a boring and hard activity for them.

Such conditions, therefore, lead the researchers to have an opinion that there might be something wrong with the instruction implemented so far. Therefore, factors affecting the success of the instruction, one of which is the teacher's teaching technique, needs to be reviewed, and a better teaching technique needs to be pursued. In order to solve the problems and to improve the students' writing proficiency, the use of an appropriate method is indispensable.

In the teaching and learning of essay writing, the effective method seems to be the one that can give a significant contribution to solve the teaching and learning problems and toward the improvement of the students' writing proficiency. In other words, hopefully, the method is expected to reduce the students' mistakes in using language skills and components through practicing and exercising. For this purpose, the researchers would like to use Student Teams-Achievement Division (STAD)as an alternative solution. STAD refers to a variety of cooperative learning methods in which students work in small groups to help one another learn academic content (Slavin, 1998:3). The formulation of research problem is:How can the implementation of STAD improve the students' writing skill in essay writing? In Which itmay improve the students' activeness in the process of teaching-learning of essay writing and students' writing product in components of essay writing (content, organization and language use) 


\section{The Nature of Writing}

Writingrefers to an activity to produce and express ideas, thoughts, and feelings in a written form. Writing activity involves the encoding of a message that needs to be transferred into written language. Brown (2011, 343) describes writing as a process of putting ideas down on paper to transform thoughts into words, to sharpen main ideas, and to give them structure and coherent organization. In producing a coherent discourse, writers need to exploit what they already know about the subject at hand and integrate it with the information from other sources. The knowledge of grammar and discourse function must be drawn together. In order to do such things in writing, learners need to acquire some micro skills as Brown (2001:343): (1) Produce graphemes and orthographic patterns of English; (2) Produce writing at an efficient rate of speed to suit the purpose; (3) Produce an acceptable core of words and use appropriate word order patterns; (4) Use acceptable grammatical system (5) Express a particular meaning in different grammatical forms; (6) Use cohesive devices in written discourse; (7) Use the rhetorical forms and conventions of written discourse; (8) Appropriately accomplish the communicative functions of written texts according to form and purpose; (9) Convey links and connections between events and communicate such relations as main idea, new information, given information, generalization, and exemplification; (10) Distinguish between literal and implied meaning; (11) Correctly convey culturally specific references in the context of the written text; (12) Develop and use a battery of writing strategies, such as accurately assessing the audience's interpretation.

According to Russo (in Rivers, 1983:30), writing is not necessarily a solitary activity on the part of the author but can be intensively interactive, involving the instructor, other students, and individuals outside of the formal classroom setting. She also states that writing skills can be developed through class writing, group writing, individual writing and community writing.

\section{The Teaching of Writing in EFL/ESL Context}

For the students of English as a foreign language (EFL), learning to write in English is a very complex process. To produce a piece of 
writing as written communication requires the writer's ability to use not only his or her linguistic competence but also his or her communicative competence (Mukminatin, 1997: 95).EFL/ESL students must develop communicative writing competence in the new language and learn the rhetorical structure, which probably is quite different from the rhetorical structure of their native language (He, 1989: 3637). So, in writing classrooms, teachers should help the students develop a different attitude towards writing by encouraging them to concentrate on thinking of contents and on expressing their thought clearly, rather than concentrating on avoiding mistakes (Lopes, 1991: 42-44). Simply pointing out students' grammatical mistakes should not be the end and the purpose of the teaching of writing, because good writing cannot grow merely from exercises in grammar and vocabulary choice. Since writing is basically a form of communication, it is, therefore, essential to make the teaching of writing as communicative as possible. The students must learn to write for a communicative purpose, concentrating more on how to put their message to the readers (Liu, 1991: 32-34).

\section{The Problems in the Teaching of Writing}

Writing as many people believe is the most complex one compared to the three other skills. It is the hardest part for children to master because it involves some other language components (content, organization, grammar, vocabulary, and mechanics) as the prerequisite of the written language style.Dealing with the problem in writing, Rivers (1983: 65) states two factors that are often ignored by the language teachers. Firstly, many highly articulate people express themselves very inadequately in writing their native language and it impacts their second/foreign language. Secondly, only a minority of the speakers of any language acquire the skill of writing accurately.

Furthermore, Byrne (1988: 45) categories the problem in writing into three main heading: psychological problem, linguistic problem, and cognitive problem. Psychological problem means that writing is a solitary activity, without the possibility of interaction or directly feedback from a reader. This leads writing task as an imposed 
activity and lack confidence as writer.Linguistic problem refers to the context of writing itself in which a writer needs to express his/ her ideas carefully or explicitly through sentences structures that have been linked together and sequenced, so those sentences are easy to understand. Cognitive problem means that writing is learned through a process of instruction. In other word, a writer needs to master the written form of language and to learn certain structures, which are less used in speech in order to make the communication more effective. Meanwhile, a writer needs to learn how to organize his/her ideas in such a way that can be understood by readers who are not present.

\section{Essay Writing}

Essay is a group of paragraphs that develops one central idea (Smalley, 2001: 105). It is in line with Oshima and Hogue's statement $(1998,118)$ that an essay is a group of paragraphs about one topic. Basically, writing an essay is quite similar to writing a paragraph in which it is written to discuss and develop one topic, and it emphasizes on unity and coherence of necessary quality. However, the topic developed in an essay is too complex and too broad to be developed in a single paragraph. From the Figure 1 below there are three main parts of an essay: introductory paragraph (beginning), body paragraph (middle), and concluding paragraph (last) (Gardner, 2005: 104; Oshima\& Hogue, 1998: 118, and Smalley, 2001: 105). One example of an essay is comparison and contrast, the process of examining two or more things in order to establish their similarities or differences. In order to understand each of the two things more clearly, and to make judgment about them, or to look a fresh insight into something that is similar, or to demonstrate that one thing is superior to another. 


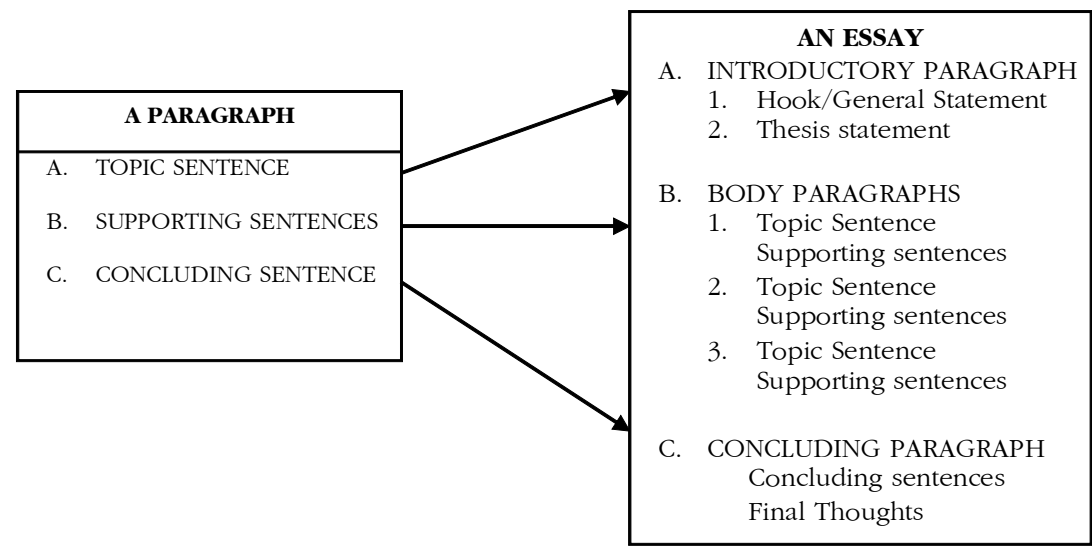

Figure 1. The Basic Plan of Paragraph and Essay. (Adopted from Oshima\& Hogue, 1998:118)

\section{The Assessment of Writing}

Assessment is a process of getting information about students' development or progress and their achievement in the teaching and learning process. In relation with the writing skill, Mukminatin(1997: 34) writes, "Writing assessment refers to a procedure in judging a piece of writing by using a particular technique". Two basic approaches in the assessment are known as direct and indirect approaches. The direct approach requires students to write an actual essay by organizing their ideas into a unified text. The indirect approach, on the other hand, does not ask the students to write an actual essay but it asks them to respond the questions about writing or to do a particular task related to writing skills. The first type is similar to a free writing test and categorized as the complex form of text, whereas the second type is a guided writing test and it is simpler than the first one.

Meanwhile, Tompkins and Hoskisson (1994: 272-273) states that in order to know the students' progress or development and their ability in writing, there are three kinds of assessment we can use: informal, process, and product assessment. Informal assessment is a kind of on-going assessment used to keep track of students' progress in writing. In addition, Brown (2001:402) states that informal assessment is involved in all incidental, unplanned evaluative 
coaching and feedback on tasks designed to elicit performance but not for the purpose of recording results and marking fixed judgment about a student's competence.

Process assessment is the assessment that is done during the teaching and learning process (Latief, 1990: 14). In connection with the teaching and learning of writing, Tompkins (1994: 379) states, "process assessment is designed to probe how students write, the decisions they make as they write, and the strategies they use". Three kinds of tools are used for conducting process assignment, namely (1) writing process checklist, (2) student-teacher assessment conference, and (3) self-assessment.Product assessment means giving score to students' writing product. The three techniques of scoring can be used to assess the students' writing namely primary trait, holistic scoring rubric, and analytic scoring rubric (Mukminatien, 1997:30; O'Malley \& Pierce, 1996:45; Tompkins \&Hoskisson, 1994: 272-273). Each of the scoring system has advantages and weak points.

\section{Student Teams-Achievement Division (STAD)}

STAD is one kinds of cooperative learning technique in which students are assigned to four members learning teams that are mixed in performance level, gender and ethnicity. The teacher presents a lesson and the students work within their teams to make sure all team members have mastered the lesson. Then, all students take individual quizzes on the material, at which time they may not help each another.STAD is a general method of organizing the classroom rather than a comprehensive method of teaching any particular subject; teacher use their own lesson and other materials. STAD consists of five major components, namely class presentation, teams, quizzes, individual improvement scores, and team recognition.

The main idea behind STAD is to motivate students to encourage and help each other to master skills presented by the teacher. If students want their team to earn team rewards, they must help their teammates to learn the material. They must encourage their teammates to do their best, express norm that learning is important, valuable and fun. Students work together after the 
teacher's presentation. They may work in pairs and compare answers, discuss any discrepancies, and help each other with any misunderstandings. They discuss approaches to solve problem, or they may quiz each other on the content they are studying. They work with their teammates; assess their strength to help them succeed on the quizzes.

\section{Previous Studies}

Concerning cooperative learning, Najamuddin (2009:104) found that STAD could improve the students' reading comprehension. Anwar (2006:112) conducted his research using STAD on Biology subject, and he found that STAD can improve students' motivation and achievement. Ruslin (2003: 95) conducted his research to solve the problem faced by his students in comprehending reading text through cooperative learning. These study shows that group works can improve the students' ability in reading comprehension. By working in groups, the students can share the ideas and help each other to comprehend a reading text.

Astuti (2004: 107) found that the students' grouping can motivate the group's members, to develop social interaction by sharing responsibilities and ideas in completing the task assigned. After the implementation of cooperative learning strategy (small group discussion and $\mathrm{CIRC}=$ Cooperative Integrated Reading and Composition), the students' paragraph writing skills are improved, but their writings still contain some errors. The problems deal with the students' incapability of expressing ideas which are mainly caused by the lack of vocabulary and low grammatical mastery. Therefore, the writing program should be designed appropriately to assist the students to develop their writing ability in a frame of their needs, relate it to their real life and it is not only solely intended to fulfill the teacher's request to produce the best result of writing product. In this way, the students will feel that writing is useful for them.

The design of this research is Classroom Action Research (CAR) adapted from Kemmis and Mc Taggart (1998: 5) since this research deals with the teaching learning strategy to improve students' writing skill. They state that action research is trying out ideas in 
practice as a means of improvement and as a means of increasing knowledge about curriculum, teaching and learning.

The present study was conducted at the fourth semester students (class A) of English Education study program of STAIN Kediri in academic year 2012-2013. In this semester, the students take Writing 3 as a compulsory course. The study used both qualitative and quantitative data. The qualitative data is taken from the process of teaching and learning writing, the students' attitude and involvement during the implementation of STAD in the process of writing. Observation sheet and field notes will be used as the instruments. The quantitative data is taken from the students' writing product which is taken at the end of each cycle of the learning process in writing, and will be scored using analytical scoring rubric for writing.

In this study, collaborative research approach is implemented in which the classroom teacher helps the researcher in doing the research. This is in line with Koshy's ideaof the significance of the collaborator (Koshy, 2005: 40) claiming that the need for collaboration or cooperation in action research is of paramount importance for the success of the research. The collaborator helps the researcher in doing the steps of the research: making a plan of the action, implementing the action, observing, and reflecting. In this study, the researcher implements the planning while the collaborator observes both the researcher's performance in teaching of writing using STAD and the students' response and progress during the process of learning toward the implementation of STAD.

The research procedures used are: (1) planning action, (2) implementing of action, (3) observing of action, and (4) analysis and reflecting (see Figure 2). This study is considered successful if it meets the following criteria: 


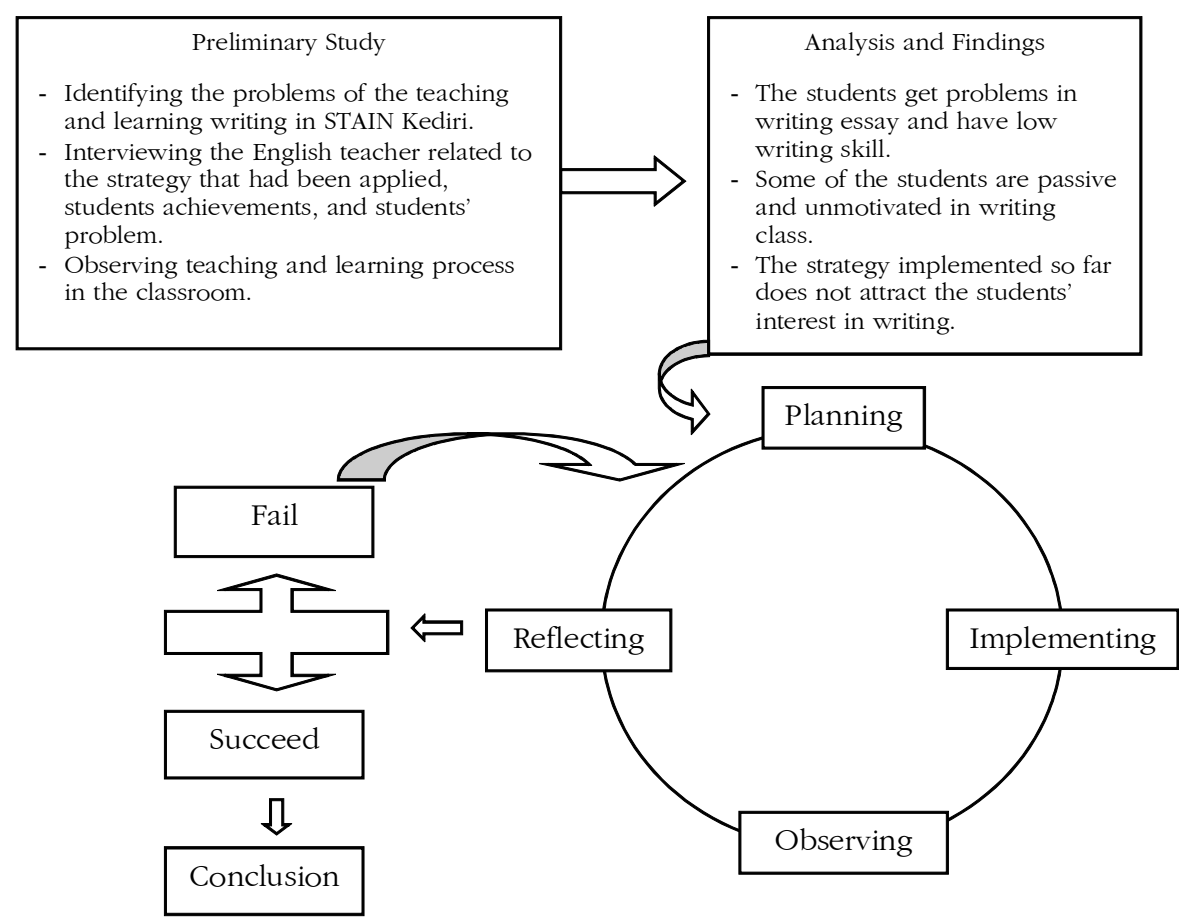

Figure 2. The Procedures of Classroom Action Research (Adapted from Kemmis and Mc Taggart cited in Koshy, 2007:4)

a. Most of students' or at least $75 \%$ students have positive response and active involvement. It means that if the result shows that most students or at least $75 \%$ students take part and are actively involved during the teaching and learning process, so the criterion is met. In the contrary, If most students are not active involved in the writing process, so the criterion is not met. The students' activities are analyzed using observation sheet for students and field notes.

b. The students can achieve at least good level of their writing products in all components of the scoring guide. The students' writing products will be analyzed using analytical scoring rubric as scoring guide, in which consists of three writing components: the content (idea), organization, and language use. The scoring guide can be seen in Appendix A. This research is considered successful if at least $75 \%$ students are able to achieve good level 
as minimum level at three components of writing. The essay is categorized as "good level" if (1) the content presents information (explanation) with well-chosen detail across the essay; (2) the organization of the essay is clear; and (3) the language use presents effective but occasional errors of word choice, sentence constructions and some grammatical inaccuracies, but do not affect meaning.

\section{The Implementation of the Action Plan in Cycle I}

Before implementing the action in Cycle I, the researcher with the collaborator prepared the lesson plan. Carefully designed, comprehensive plans will give a positive effect on the students' learning since a plan can help the teachers to remind what they intended to do (Harmer, 2000:121). The lesson plan in Cycle I was made to achieve the criteria of success presented previously in which they are made based on data analysis in the preliminary study. The plan was accomplish in four meetings, and the time allocated for each meeting was 100 minutes. Beside the lesson plan, the researcher also prepared the observation sheet and field notes as instruments of the research.

The next step is the implementation, the researcher acted as the lecturer conducting the teaching and learning process, while the collaborator observed the teaching and learning activities in the classroom. As stated previously that the plan in cycle I consisted of four meetings, and the time allocated for each meeting was 100 minutes. However, in the implementation, the meeting class was change into 5 meetings. The observation is emphasized on the students' activities during the implementation of the planning (teaching and learning process using STAD method).In order to know whether or not the implementation of the action plan in Cycle I was successful, both researcher and the collaborator analyzed the collection of the data from the observation checklist, field notes, and students writing products. The analysis was focused on the result of the teaching and learning process, and the students' product of writing as the students' learning result. 
The result showed that most students were involved actively in the teaching and learning process of writing. It was proved by the result of the observation checklist in which the total point earned was 82 out of 92 . It means that $89 \%$ of the students were actively involved the process. Moreover, the group discussion made them motivated more to studyand got more chance to be active. The analysis on the students' product of writing was done using an analytical scoring rubric. Based on the result of the analysis, it was found that the students gained significant improvement. It was indicated by the students' improvement in their final drafts in each component of writing. However, they were still weak in term of content and the language use (Tabel 2).

\section{Table 2}

The Summary of the Students' Score of the Writing Product in Cycle I

\begin{tabular}{lllll}
\hline Components of Writing & Excellent & Good & Fair & Poor \\
\hline Content & $25 \%$ & $46 \%$ & $29 \%$ & $0 \%$ \\
Organization & $26 \%$ & $64 \%$ & $10 \%$ & $0 \%$ \\
Language use & $14 \%$ & $54 \%$ & $32 \%$ & $0 \%$ \\
\hline
\end{tabular}

In the component of content, $71 \%$ of the students were able to achieve minimum level prescribed for successful product in writing a comparison and contrast essay. There were $25 \%$ of the students who reached excellent level; $46 \%$ reached good level; $29 \%$ reached fair level, and there was no students who got poor level. While In the component of organization, $90 \%$ of the students were able to achieve minimum level prescribed for successful product in writing a comparison and contrast essay. There were $26 \%$ of the students who reached excellent level; $64 \%$ reached good level; $10 \%$ reached fair level, and there was no students who got poor level. On the other hand, language use, $68 \%$ of the students were able to achieve minimum level prescribed for successful product in writing a comparison and contrast essay. There were $14 \%$ of the students who reached excellent level; $54 \%$ reached good level; $32 \%$ reached fair level, and there was no students' who got poor level. 
Based on the analysis result of the teaching and learning process of writing and the students' product of writing in Cycle I, it could be concluded that: (1) Related to the teaching and learning process, this study has met the criteria of success prescribed, in which most of students' or at least $75 \%$ students have positive response and actively involved in the teaching and learning process. It was proved by the result of the observation based on observation checklist for students' activities. The total point earned was 82 out of 92 , or $89 \%$ of the students were actively involved in the process of teaching and learning. It was included in the very good category. Moreover, the group discussion made them motivated more to study, felt un-boring, and got more chance to be active. (2) In the students' writing product, the students had not achieved the criteria of success prescribed, in which at least $75 \%$ of the students should achieve at least good level of their writing products in all components of writing. In the content criteria, $29 \%$ of the students were not able to achieve the minimum level; $10 \%$ in the organization, and $32 \%$ of the students failed in achieving the minimum level in language use.

Finally, it was concluded that the study was not successful enough since there was one criteria of success which had not been reached yet. Therefore, the action continued in the next cycle. Then, the researcher and the collaborator revised and planned the activities in the teaching and learning process to be implemented in the next Cycle. First, the researcher and the collaborator analyzed what criteria of success had not been achieved by the students. From the analysis, it was found that the students were still weak in composing their writing. They still had problems in their writing components (content, organization and language use). Therefore, the researcher and the collaborator planned to overcome those problems.

\section{The Implementation of the Action Plan in Cycle II}

As stated previously, the Cycle I was not successful enough since there was one criteria of success which had not been reached yet. The students were still lack in their writing components. Therefore, the researcher and the collaborator planned actions for activities in the Cycle II to overcome the weaknesses. First, we planned how to 
overcome the students' weaknesses in content area. We decided to ask the students to discuss more about the topic with their friends and find some articles to back up their writing. The articles also can be used as material in group discussion. Then, the students must write the result of group discussion individually, and take some points from the result to be included in their drafts. Since in the first cycle, it was found that some students only sat in group without involving in discussion, and they also did not use the articles to support their writing.

Related to the students' weaknesses in organization, the researcher and the collaborator will give more exercises about the organization of comparison and contrast essay before drafting process. Since in the first cycle, the students just explained about their topic without pay more attention on the organization of the essay. Some of the students wrote to abroad and no relation with the topic. They just explained two people or things without compare them.

To overcome the students' weaknesses in language use, the researcher and the collaborator planned to give more exercises about the grammar especially in the comparison and contrast transition expression. Furthermore, we also planned to give exercises on language focus of comparison. The plan in Cycle II consisted of three meetings, and the time allocated for each meeting was 100 minutes(teaching and learning process using STAD method).

In order to know whether the implementation of the action plan in Cycle II was successful, as like in Cycle I, both researcher and the collaborator analyzed the collection of the data. Similar to Cycle I, the analysis was focused on the result of the teaching and learning process, and the students' product of writing as the students' learning result.The result of the observation in Cycle II based on observation checklist for students' activities showed that most students were involved actively in the teaching and learning process of writing. It was proved by the result of the observation checklist in which the total point earned was 87 out of 92 . It means that $94.5 \%$ of the students were actively involved the process of teaching and learning in Cycle II. It was higher than the percentage in Cycle I. The students felt enjoy in the class activities. 
Similar to Cycle I, the analysis on the students' product of writing was done using an analytical scoring rubric. Based on the result of the analysis, it was found that the students gained significant improvement. It was indicated by the students' improvement in their final drafts in each component of writing (content, organization, and language use). The summary of the result can be seen on the Table 3. The result of the analysis of the students' products was described elaborately as follows.

\section{Table 3}

The Summary of the Students' Score of the Writing Product in Cycle II

\begin{tabular}{lllll}
\hline Components of Writing & Excellent & Good & Fair & Poor \\
\hline Content & $39 \%$ & $57 \%$ & $4 \%$ & $0 \%$ \\
Organization & $39 \%$ & $61 \%$ & $0 \%$ & $0 \%$ \\
Language use & $29 \%$ & $50 \%$ & $21 \%$ & $0 \%$ \\
\hline
\end{tabular}

Related to the component of content, $95 \%$ of the students were able to achieve minimum level prescribed for successful product in writing a comparison and contrast essay. There were $39 \%$ of the students who reached excellent level, and $57 \%$ reached good level. However, $4 \%$ of the students still reached fair level, and there was no student who got poor level. Furthermore the component of organization, $100 \%$ of the students were able to achieve minimum level prescribed for successful product in writing a comparison and contrast essay. There were $39 \%$ of the students who reached excellent level; $61 \%$ reached good level, and there was no students who got fair or poor level. But in the component of language use, $79 \%$ of the students were able to achieve minimum level prescribed for successful product in writing a comparison and contrast essay. There were $29 \%$ of the students who reached excellent level, and $50 \%$ reached good level. However, $21 \%$ of the students reached fair level, and there was no students' who got poor level.

Compared to the result of Cycle I, the students in Cycle II reached higher average score in the whole components of writing. The comparison between the students' average score in Cycle I and in Cycle II can be seen in Table 4. This research is considered 
successful if at least 75\% students are able to achieve good level as minimum level at three components of writing.

Table 4

The Comparison of the Students' Average Score in Cycle I and Cycle II

\begin{tabular}{lcccccccc}
\hline \multirow{2}{*}{$\begin{array}{l}\text { Components of } \\
\text { Writing }\end{array}$} & Excellent $(\%)$ & \multicolumn{2}{c}{ Good (\%) } & \multicolumn{2}{c}{ Fair (\%) } & \multicolumn{2}{c}{ Poor (\%) } \\
\cline { 2 - 9 } & Cycle & Cycle & Cycle & Cycle & Cycle & Cycle & Cycle & Cycle \\
& I & II & I & II & I & II & I & II \\
\hline Content & 25 & 39 & 46 & 57 & 29 & 4 & 0 & 0 \\
Organization & 26 & 39 & 64 & 61 & 10 & 0 & 0 & 0 \\
Language use & 14 & 29 & 54 & 50 & 32 & 21 & 0 & \\
\hline
\end{tabular}

Based on the analysis result of the teaching and learning process of writing and the students' product of writing in Cycle II, it could be concluded as follows: (1) For the teaching and learning process, this study has met the criteria of success prescribed, in which most of students' or at least $75 \%$ students have positive response and actively involved in the teaching and learning process. It was proved by the result of the observation based on observation checklist for students' activities. The total point earned was 87 out of 92 , or $94.5 \%$ of the students were actively involved in the process of teaching and learning. It was included in the very good category, and it was higher than the percentage in Cycle I. The students felt enjoy in the class activities; (2) Related to the students' writing product, the students achieved the criteria of success prescribed, in which at least $75 \%$ of the students should achieve good level of their writing products in all components of writing. In the content criteria, $96 \%$ of the students were able to achieve the minimum level; $100 \%$ in theorganization and $79 \%$ of the students were also able to achieve the minimum level.

Finally this study provides more evidence that the implementation of Student Teams-Achievement Division to the teaching of writing is effective not only in improving the students' writing skill, but also students' activeness in the process of teaching and learning. It was also indicated by the previous studies (Ruslin, 2003: 95; Astuti, 2004: 107; Najamuddin, 2009: 104). The students' activeness was caused by the existence of students' grouping in which it can 
motivate the group's members, develop social interaction by sharing responsibilities and ideas in completing the task assigned (Slavin, 1998: 272).

The STAD teams or groups reprensented a cross-section of the class. Each group consisted of four or five students having different performance: high, average and low. Students' grouping can promote students' positive interdepence and individual accountability, in whichgroup members are linked with each other in a way that one cannot succeed unless everyone succeeds, and each member hasresponsibility for contributing one's efforts to accomplish the group's goals(Johnson and Johnson, 1991: 10; Kessler, 1992: 8).The field notes revealed that most of the students were enjoyed learning cooperatively, and this method could attain the teaching and learning objective effectively. The observation checklist revealed that $89 \%$ of the students were actively involved the process of teaching and learning in Cycle I, and $94.5 \%$ in Cycle II.

The findings of the research showed that the implementation of Student Team-Achievement Division (STAD) could improve the students' writing skill. It was indicated by the students' writing skill before the implementation and after the implementation of the method. From the preliminary study, it was revealed that the students' writing skill was low in which no more than $50 \%$ of students got 'good' level in marking scheme of all components of writing (content, organization, and language use). However, after the implementation of STAD, the students' writing skill gradually improved.

The improvement of students' writing skill can be seen from the products of students' writing in Cycle I and Cycle II. The result of students' writing skill in Cycle I showed that $71 \%$ of the students were able to achieve'good' level as the minimum level prescribed for successful writing product in term of content, $90 \%$ in term of organization, and $68 \%$ in term of language use. Unfortunately, the improvement of students' writing skill in Cycle I did not achieve the criteria of success in term of content and language use. However, in the end of Cycle II, the students' writing skill improved $95 \%$ in term of content, $100 \%$ in term of organization, and $79 \%$ in term of language use. The results in Cycle II were met the criteria of success. 
The improvement of students' writing skill was caused by cooperative learning experiences. As Johnson and Johnson's study (1991: 52) that cooperative learning experience promoted higher achievement than individual and competitive learning experience.

\section{Conclusion}

In accordance with the research findings and the discussions of the study, it can be conclude that the implementation of Student Team Achievement Division (STAD) to improve students' writing ability in essay writing has been successful. It is proved by the result of the study in which the whole criteria of success prescribed have been achieved. The achieving of the criteria of success is described elaborately as follows.

The first criterion of success is related to the teaching and learning process. In this study, it has fulfilled the criterion of success prescribed in which most of students or at least $75 \%$ of the students are actively involve during the teaching and learning process. The result of the observation checklist showed that $89 \%$ of the students were actively involved the process in Cycle I, and $94.5 \%$ of the students were actively involved the process of teaching and learning in Cycle II. Moreover, the group discussion made them motivated more to study, felt un-boring, and got more chance to be active. They felt enjoy in the class activities.

The second criterion of success is related to the students' writing product. In the first cycle, this study has not met yet the criteria of success prescribed in which at least $75 \%$ of the students are able to achieve good level as minimum level at three components of writing. The result of students' writing product in Cycle I showed that the students were still weak in content and language use.In term of content, $71 \%$ of the students can achieve good level in marking scheme, and $68 \%$ in term of language use. It is still below the criteria of success. However, in the second cycle, this study has met the criteria of success prescribed. The result of students' writing product in Cycle II showed that more than $75 \%$ of the students achieved the criteria of success. $96 \%$ of the students can achieve good level in marking scheme in term of content, $100 \%$ in term of organization, and $79 \%$ in term of language use. 


\section{References}

Basuni. 2004. Using Questioning Technique to Improve the Ability of the Second Year Students of SLTP Negeri 1 Haruai in Writing Paragraph.Unpublished Master Thesis. Malang: State University of Malang.

Brown, H.D. 2001.Teaching by Principles: An Interactive Approach to Language Pedagogy, New York: Addison-Wesley Longman

Byrne, D. 1988. Teaching Writing Skill. London: Longman.

Cohen, A.D. 1994. Assessing Language Ability in the Classroom, Second Edition.Boston: Heinle\&Heile

Gardner, P. 2005. New Directions: reading, Writing, and Critical Thinking (2nd). New York: Cambridge University press, p.104.

Hadfield, C. \& Hadfield, J. 1990. Writing Games. Edinburg: Thomas Nelson \& Son.

Harmer, J. 2001. The Practice of English Teaching, $2^{\text {rd }}$ Ed. Essex: Pearson Educational.

He, G.Q. 1989. Let the Student Write Actively. Forum, 27 (2): 36-37.

Jacobs, H.L.et.al.1981. Teaching ESL Composition: A Practical Approach. Massachusetts: Newbury House.

Johnson, D.W., and Johnson H. 1991.Learning Together and Alone: Cooperation, Competition and Individualization (Third Edition). Massachusetts: Allyn and Bacon.

Kemmis\&Mc Taggart. 1998. The Action Research Planner. Geelong: Deakin University Press.

Kessler. 1992. Cooperative Language Learning, a Teacher's Resource Books.New Jersey: Prentice Hall

Koshy, V. 2005.Action Research for Improving Practice. London: Paul Chapman Publishing.

Langan, J. 1985. College Writing Skills with Readings. New York: McGraw Hill.

Latief, M. A. 1990. Assessment of English Writing Skill for Students of English as Foreign Language at the Institute of Teaching Training and Education (IKIP) Malang.Dissertation.Univesity of IOWA. 
Liu, C. 1991. Helping Students Prepare Psychologically to Write in English. Forum, 29 (4): 32-34.

Lopes, D. 1991.From Reading to Writing Strategies.Forum, 29 (4): 42-44.

Mukminatin, N. 1997.The Difference of Students' Writing Achievement Across Different Courses Levels. Unpublished Dissertation. Malang: State University of Malang.

Najamuddin. 2009. Implementing Cooperative "STAD" Method to Improve the Reading Comprehension Achievement of the Students' of MAN I Kota Bima. Unpublished Master Thesis. Malang: State University of Malang.

Nunan, D. 1991. Teaching Methodology.A text Book for Teachers. Hertfordshire: Prentice Hall International.

O'Malley, J.M. and Pierce, L.V. 1996. Authentic Assessment for English Language Learning, Practical Approach for Teacher. New York: Addison-Wesley.

Oshima, Alice and Ann Hogue. 1998. Writing Academic English. New York: Addison-Wesley.

Raimes, A. 1987.Techniques in Teaching Writing. Oxford:Oxford University Press.

Rivers, W.M. 1983. Teaching Foreign Language Skills. Chicago: The University of Chicago Press.

Slavin, R. E. 1998. Cooperative Learning: Theory, Research and Practice. Massachusetts: Allyn\&Bacon.

Smalley, R.L. et al. 2001. Refining Composition Skills; Rhetoric and Grammar. Boston: Heinle\&Heinle.

Spendel, V. \&Stiggins, R.J. 1990.Creating Writer. London: Longman Sukidin, Basrowi, Suranto. 2002. Manajemen Penelitian Tindakan Kelas. No city: InsanCendekia.

Tompkins, G.E., \& Hoskisson, K. 1994. Language Arts: Content and Teaching Strategies. New York: Macmillan 